\title{
Monitoring of The Impact of Road Salting On Spruce Forest Ecosystem In The Vicinity of The Highway D1 In The Bohemian-Moravian Highlands, Czech Republic
}

Jitka Hegrová ( $\nabla$ jitka.hegrova@cdv.cz)

Transport Research Centre https://orcid.org/0000-0003-1717-6187

Lubomír Prokeš

Masaryk University: Masarykova Univerzita

Petr Anděl

Technical University of Liberec: Technicka Univerzita v Liberci

Martina Bucková

Transport Research Centre

Vilma Jandová

Transport Research Centre

Karel Effenberger

Transport Research Centre

Roman Ličbinský

Transport Research Centre

\section{Research Article}

Keywords: Spruce ecosystem, winter road maintenance, salt distribution, contamination

Posted Date: June 3rd, 2021

DOI: https://doi.org/10.21203/rs.3.rs-496632/v1

License: (9) (i) This work is licensed under a Creative Commons Attribution 4.0 International License. Read Full License

Version of Record: A version of this preprint was published at Environmental Science and Pollution Research on September 16th, 2021. See the published version at https://doi.org/10.1007/s11356-02116468-9. 


\section{Abstract}

Monitoring of pollution in the vicinity of roads connected to winter road maintenance is one of the important tools for optimising winter maintenance technology and reducing its environmental impact. The aim of this study was to determine the relationship between winter road maintenance and the increased concentration of sodium ion to characterize the harm caused by the de-icing agents on selected types of individual components grown in the Norway Spruce ecosystem. The model area is located in the immediate vicinity of the D1 motorway connecting Prague and Brno (Czech Republic), at 103rd kilometer. The area is thus exposed to long-term contamination from automobile transport and the monitoring was carried out for three consecutive years. A clear effect of the de-icing agents on conifers near the road has been demonstrated by the symptoms of salt damage visually observed in close proximity to the road (at a sampling distance of $5 \mathrm{~m}$ ). The needles of these spruce trees also showed increased sodium concentrations, regardless of the age of the needles. The study also confirms that sodium accumulates in all selected components of the analysed ecosystem (moos, humus, soil). The sodium concentration has been found to decrease with increasing distance from the road for all of the components.

\section{Introduction}

Transport is generally perceived as an important factor affecting the quality of the environment. The intensity of transport in Europe has significantly increased since the beginning of the 1960s (Fischel, 2011). At the same time, chloride-based de-icing agents, sand, and chemical materials (Hofman et al. 2012) started to be used for road maintenance. Sodium chloride is the most commonly used material applied as a preventive anti-icing agent and as de-icing agent, sometimes in a mixture with calcium chloride (Merrikhpour and Jalali, 2013; Munck et al., 2010). Winter chemical maintenance of roads is one of the significant factors having negative effects on the environment (Fay et al., 2013; Fay and Shi, 2012). After the application, sodium chloride particles are mobilized by melting snow or ice and rainfall and subsequently enter the soil environment, surface water, rock environment and groundwater (Howard and Beck, 1993) The deterioration of health of plants growing around roads is one of the most easily detectable effects of the use of de-icing salts. Vegetation along the roads thus becomes an important indicator pointing out to an increased use of de-icing salts (Langen and Prutzman, 2006; Černohlávková et al., 2008). The effects of chemical de-icing materials on soil (Hääl et al., 2008; Ramakrishna and Viraraghavan, 2005) show that salt remains bound in the soil during spring and its concentration further increases during summer as the amount of water in the soil decreases; by autumn most of the salt is washed out. However, this means that during the period of plant growth, the salt concentration in the soil water is the highest compared to other times of the year (Pedersen et al., 2000; Vignisdottir et al., 2019). Other impacts of winter road maintenance on vegetation include decrease in biomass or disruption of photosynthesis caused by reduced chlorophyll levels, the reduction of the biovaliability of nutrients by soil alkalising. However, this kind of treatment can damage the plants or trees. It has been observed that deciduous trees are more sensitive to frost when salt is accumulates in the leaves (Czerniawska-Kusza et 
al., 2004; Dmuchowski et al., 2011; Gałuszka et al., 2011; Munck et al., 2010; Viskari and Kärenlampi, 2000). Kayama (Kayama et al., 2003) also described deterioration in the growth of conifers such as Norway spruce (Picea abies) and Glehn's spruce (Picea glehnii) planted along roads. The authors focused on the effect of de-icing salts in soil and snow on the vitality and health of these conifer species. Sodium and chlorine ions were found to be accumulated in the needles, especially. Besides that, the spruce in the contaminated area were also affected by the suppression of the tree growth. According to previous studies (Schulze, 1989; Izuta, 1998), air pollution is one of the main reasons for the decrease in the number of growing spruce trees in Europe. Compared to other woody plants, spruces are highly sensitive to salinity (Bogemans et al., 1989; Larcher, 1995), and, therefore, spruce is a suitable bioindicator of the influence of de-icing salts used for winter road maintenance (Zítková et al., 2018). Suchara (Suchara et al., 2011) monitored the influence of heavy metals and other elements, including sodium, to detect contamination from anthropogenic sources in industrialized areas on selected biomass samples: moss, grass, one- or two-years old needles. Specific plants have been used in Europe for biomonitoring since the 1980s, for example, a program using moss for monitoring every 5 years. Angold (Angold 1997) investigated the effect of road maintenance on heathland vegetation at localities near the main road. He found that traffic affects localities up to a maximum distance of $200 \mathrm{~m}$, depending on the intensity of the traffic. Effects of de-icing salts on ecosystems in the Bavarian Forest were also studied (Křenova et al., 2018). Experiments with seedlings of various trees grown from seed and exposed to salting have shown that Norway spruce was most sensitive and Scots pine was the most tolerant to the salting in comparison with other tree species such as Norway maple (Acer platanoides) or White birch (Betula pendula) (Fostad and Pedersen, 2000). Published studies focus usually on the impact of winter maintenance on the soil environment in the Czech Republic (Černohlávková et al., 2008; Hofman et al., 2012) and on bioindication of the effect of de-icing material on spruce and pine needles (Zítková et al., 2018; Zítková et al., 2021). Problem of impact of winter maintenance on forest cover is usually focused only on effect of splashed brine to the border trees, on induced necroses and dieback of needles, especially. The main goal of these article is to point out the transport of sodium and chloride ions in form of aerosol to distances up to tens or hundreds of meters. Because of it affects all the ecosystem, its various components (needles of different age, fallen needles, humus, soil, grass, moos and lichen) were sampled in three various distances from the road. The aim of this study is to evaluate the long-term impact of winter road maintenance on the spruce forest ecosystem located in the immediate vicinity of a highway in Czech Republic. The research is based on the determination of accumulation and distribution of $\mathrm{Na}$ ions in the individual components of the selected ecosystem.

\section{Material And Methods}

\subsection{Sampling}

In the selected ecosystem, soil samples (collected near the analysed conifers), needles of spruce (Picea abies), samples of forest grass (Avenella flexuosa) and samples of Schreber' red-stemmed moss (Pleurozium schreberi) were collected. The soil was collected in two layers: a humus layer from the depth 
of up to $20 \mathrm{~cm}$ and the subsoil layer. Whole branches were removed from the trees and subsequently cut, and their needles were divided according to age, i.e., according to the duration of exposure to toxic substances. These are herbaceous buds (age about 2 months (OY), one-year- and two-year-old needles $(1 Y, 2 Y)$ and mixed needles $(3+$ years, $3+Y)$. The samples of fallen needles were also collected. Grass is a model of the primary producer typical for the given ecosystem through which toxic substances can enter food chains. Moss serves as an accumulation indicator, especially indicating accumulation of heavy metals. Due to its very small root system, the moss sample is mainly used to represent contaminants captured from the air (Suchara et al., 2011).

Sampling took place in three spring sampling campaigns in $2018,2019,2020$. One autumn sampling campaign (2018) was also performed to detect changes in Na concentrations in the individual samples of the selected spruce forest during the year.

The sampling site was selected according to the basis of the assessment of contamination potential (Zítková et al., 2018), where the position (location) of the area (forest ecosystem analysed) in respect of the road is evaluated. The location selected for the three-year monitoring falls into the 3rd category areas with the highest contamination potential, the trees immediately next to the road and below the level of the road (the runoff washed from the road and other traffic contamination more easily enter the analysed ecosystem). The condition of the trees was visually assessed during the sampling (1st class healthy tree, 2nd c lass - slightly damaged tree, 3rd class - damaged tree) (Zítková et al., 2018), where trees growing in close proximity to the road (at about $5 \mathrm{~m}$ ) were visibly damaged due to winter maintenance (brown colouring of needles, irregular, i.e., caused by the splashing of saline solution from the road); there was also a greater amount of fallen needles indicating poor health (class 3 ).

To enable assessing the contamination range, samples were collected at three distances from the road: 5 $\mathrm{m}$ (area close to the road where the analysed ecosystem begins), $20 \mathrm{~m}$ and $100 \mathrm{~m}$ (considered as a background area). Based on these distances, the results were also sorted into three categories. Used sampling methodology was based on known mechanisms of salt spreading to the environment. Samples from distance up to $5 \mathrm{~m}$ represent immediate and maximum effect via splashing of brine with going cars. A practically evaluated distance $20 \mathrm{~m}$ is a limit, where contamination via snowploughing, milling and water splashing on the road can affect the environment. Distance $100 \mathrm{~m}$ was then chosen as local background, where contamination via aerosol is only possible.

\subsection{Chemical analysis}

\subsubsection{Preparation of plant material}

Samples of needles, grass and moss were dried in laboratory at room temperature before grinding; needles were ground using laboratory grinding mill (set to the size $<2 \mathrm{~mm}$ ), other samples were ground using oscillating mill $(<0.63 \mathrm{~mm})$. Homogenised plant material was weight in amount $0.2000 \mathrm{~g} \pm 0.0500 \mathrm{~g}$ to the Teflon digestion vessels. Nitric acid sub-boiled $(10 \mathrm{~mL})$ and hydrogen peroxide ultrapure $(2 \mathrm{~mL})$ were added and after leaching for $30 \mathrm{~min}$ were samples digested - in three replicates each, at temperature 
of $210^{\circ} \mathrm{C}$ and pressure 30 bar in a high pressure and high temperature microwave digestion system SW$4+$ (Beghof, Germany). The final volume $25 \mathrm{ml}$ of digests was achieved by addition of ultrapure water (Merck Millipore, Germany).

\subsubsection{Soil preparation}

Soil samples were dried at room temperature before sieving (mesh size $2 \mathrm{~mm}$ ) and ground to fine fraction in oscillating mill $(<0.63 \mathrm{~mm})$ for a qua regia extraction method (ISO 11466 standard: Soil quality Extraction of trace elements soluble in aqua regia). Homogenised soil samples were wight in amount $1.000 \mathrm{~g} \pm 0.0500 \mathrm{~g}$ to the Teflon vessels (in two replicates each), $10 \mathrm{~mL}$ aqua regia sub-boiled was added and samples were digested at temperature $200^{\circ} \mathrm{C}$ and pressure $30 \mathrm{bar}$ in the microwave system SW-4+ (Berghof, Germany). Ultrapure water (Merck Millipore, Germany) was used for diluting the digests to final volume of $50 \mathrm{ml}$.

\subsubsection{Instrumentation}

For determination of sodium concentrations (and other 20 elements except chlorine) mass spectrometry with inductively coupled plasma (ICPMS/MS Agilent 8800, Agilent Technologies, Japan) were used under these conditions: the forwarded RF power $1550 \mathrm{~W}$, carrier gas Ar flow rate 1.07 L.min ${ }^{-1}$, integration time per $\mathrm{Na}$ isotope $0.1 \mathrm{~s}$ in used helium single quadrupole collision mode, helium cell gas flow rate $4 \mathrm{~mL}$. $\mathrm{min}^{-}$ 1 , analyzer pressure $1.22^{\star} 10^{-3} \mathrm{~Pa}$. Concentration range $0-10 \mathrm{mg} \cdot \mathrm{L}^{-1}$ of $\mathrm{Na}$ calibration was prepared from a 1.0000 g. $\mathrm{L}^{-1}$ stock solution of a single element Na (Analytika Praha, Czech Rep.) in a matrix of $2 \%$ $\mathrm{HNO}_{3}$ (sub-boiled) and was linear in the whole range, $\mathrm{R}^{2}=100 \%$. Stock solutions of Internal standard and Tune solution (Agilent Technologies, USA) were prepared in a matrix of $2 \% \mathrm{HNO}_{3}$ (sub-boiled) and diluted by deionized ultrapure water (Merck Millipore, Germany) to final concentration. Reference materials NIST Pine Needles 1575a and QCM Metranal 33 - soil were prepared and analysed together with samples. NIST Trace elements in natural water 1640a was analysed with samples. These reference materials were selected for quality control of the analytical results.

\section{Results And Discussion}

Monitoring of chemical contamination is a suitable factor for assessing the effect of winter road treatment on the analysed biota. It is advisable to connect detailed monitoring with monitoring of soil, because of sodium is absorbed very quickly by plants by the root system in the form of $\mathrm{Na}^{+}$ions from the soil. If the concentration of the sodium ions in the soil environment increases, their concentration in plant bodies increase as well. Sodium regulates osmotic ratios in plants and affects other ions contained in the plant. An increased sodium uptake results in a decrease in the uptake of potassium, calcium and magnesium by the plant. Therefore, in the winter period, when sodium ions enter the soil in large concentrations due to the use of salt-based on sodium chloride, plants experience increase in $\mathrm{Na}$ ions absorption and decrease in nutrient uptake, such as potassium and calcium ions, leading to their damage (Larchner, 1995; Kayama et al.,2003, Gałuszka et al., 2011, Syvertsen et al., 1988; Lazof and Läuchli, 1991).According to Kayama's (Kayama et al., 2003), results, sodium concentration in one-year-old needles 
in healthy spruce $P$. abies is on average tens to hundreds of $\mathrm{mg}^{\mathrm{kg}} \mathrm{kg}^{-1}$, at a later age, it increases to about a thousand $\mathrm{mg} \mathrm{kg}^{-1}$. On the other hand, if such a tree grows very near roads or highways, the concentration of $\mathrm{Na}^{+}$in such a tree will likely significantly increase over the time. These conclusions are also confirmed by our study. Average sodium concentrations with basic statistical indicators for each sample type taken at three distances of all spring sampling campaigns are shown in Table 1. We consider trees growing at the background distance from the road, i.e. $100 \mathrm{~m}$, to be healthy. The sodium content of these conifers corresponds to the minimum concentration values specified in the Table 1. Similarly, in Kayama's study (Kayama et al., 2003), sodium and chlorine concentration in the soil of the damaged site was 5 times higher than that of the healthy site, in the snow it was twelve times higher. Compared with the results of our study, we can see that the concentration in the humus soil layer is up to 20 times higher and up to 10 times higher in the subsoil layer.

Table 1 Numeric data characteristic for Sodium in individual sample types.

\begin{tabular}{|lllllllllll|}
\hline Na $\left(\mathrm{mg}^{\mathrm{kg}}{ }^{-1}\right)$ & & & & & & & & & & \\
& $\begin{array}{l}\text { Needle } \\
\text { OY }\end{array}$ & $\begin{array}{l}\text { Needle } \\
1 \mathrm{Y}\end{array}$ & $\begin{array}{l}\text { Needle } \\
2 \mathrm{Y}\end{array}$ & $\begin{array}{l}\text { Needle } \\
3+\mathrm{Y}\end{array}$ & Moss & Grass & $\begin{array}{l}\text { Needle } \\
\text { fallen }\end{array}$ & Humus & Soil \\
\hline $\begin{array}{l}\text { No. of } \\
\text { samples }\end{array}$ & 27 & 27 & 27 & 27 & 27 & 27 & 27 & 18 & 18 \\
\hline Min. & 3.95 & 20.7 & 22.1 & 22.2 & 95.0 & 9.73 & 17.0 & 74.0 & 38.6 \\
\hline 1 quart. & 33.8 & 70.9 & 65.5 & 75.6 & 192 & 68.5 & 73.0 & 95.5 & 109 \\
\hline Average. & 100 & 998 & 1103 & 1336 & 795 & 447 & 628 & 400 & 211 \\
\hline Median & 46.8 & 239 & 403 & 639 & 397 & 169 & 213 & 107 & 134 \\
\hline 3 quart. & 327 & 3240 & 3911 & 4460 & 3186 & 935 & 2330 & 828 & 358 \\
\hline Max & 265 & 4385 & 4391 & 5204 & 2209 & 2318 & 2138 & 1914 & 812 \\
\hline SD & 91.8 & 1522 & 1528 & 1782 & 828 & 738 & 787 & 603 & 233 \\
\hline
\end{tabular}

Soil plays the fundamental role in the accumulation of toxic substances in the ecosystem and is therefore of key importance in the evaluation. The soil is also an important component of the environment in terms of the cycle of substances. Substances are usually deposited into soil from the atmosphere and the main influence of these toxic substances on the soil consists in changes of the sorption complex, A number of contaminants then enter plants from the soil environment or are washed into groundwater and surface water. The main effect of de-icing salts on soil chemism is the binding of sodium ions to the sorption complex depending on the type of soil. Sodium accumulates in soil mainly after the end of the winter period and is then gradually washed out during the year. An important factor is the total rainfall, in areas with high precipitation, sodium accumulation is lower. The effect of de-icing salt on the soil is very limited in space. It mainly concerns places of primary contamination, i.e. a narrow strip 
along the road up to approximately $10 \mathrm{~m}$ from the road (Hääl et al., 2008). De-icing salt directly affects the sides of the road and the road body, where there are not natural soils, but anthropogenic backfills. Secondary contamination occurs in areas where run-off waters from the road accumulate. The contamination decreases with the increasing distance, but it can manifest itself at a distance of up to 50 meters from the road (Löfgren, 2001), the cumulation decreases with the increasing distance from the road, but it can manifest itself at a distance of up to 50 meters from the road (Löfgren, 2001), where the contamination is highly variable depending on the season. Our research confirms the hypothesis that near the communication, the concentration of sodium in the humus layer and the subsoil layer is the highest at a distance of up to $5 \mathrm{~m}$ and it decreases with the increasing distance from the road. As can be seen in Fig.1, a clear difference in sodium concentration is visible in both cases depending on the distance from the road, where the observed sodium concentrations are compared in both soil layers collected in spring seasons; there is also evident a higher concentration of $\mathrm{Na}$ at the distance of $20 \mathrm{~m}$ from the road than at the further distance of $100 \mathrm{~m}$. At the same time, however, there is also a clear difference in sodium concentration depending on the amount of chemical de-icing agents used for winter maintenance, mainly at the distance of $5 \mathrm{~m}$ from the side of the road. In the winter periods 2017/2018 and 2019/2020, a very similar amount of de-icing salts was applied at the selected site, i.e. about 3000 tons of de-icing salt and about 600 thousand litres of brine. In contrast, winter 2018/2019 was much more demanding for the consumption of de-icing agents. That winter, more than 5000 tons of salt were used and about 1.5 million litres of brine; several thousand litres of calcium chloride were used as well (Source: the $\check{R} S D$ - Directorate of Roads and Motorways).

Samples from two layers were collected: a humus layer from the depth of up to $20 \mathrm{~cm}$ and a subsoil layer. At the distances of $5 \mathrm{~m}$ and $20 \mathrm{~m}$, the sodium content in the humus layer is higher than in the subsoil layer for all spring sampling campaigns. At the distance of $100 \mathrm{~m}$, the sodium content in both layers is roughly equal. Interestingly, in the case of samples taken in the autumn (autumn campaign 2018), there is quite the opposite trend. Sodium concentration is higher at all distances in the deeper soil layer (all data are available in the supplementary table ST1). Thus, over the course of the year, sodium ions appear to be washed (soaked) into deeper layers of soil. At the same time, there is also a gradual increase in sodium concentrations at greater distances from the road, when melting snow and precipitation distribute sodium ions to a wider area. A normal sodium content in soil is $50 \mathrm{mg} \cdot \mathrm{kg}^{-1}$. After a period of winter road maintenance, this value can increase up to 900-1000 mg. $\mathrm{kg}^{-1}$ (Semorádová, 2003). Kayama (Kayama et al., 2003) reports sodium content in the background area $88 \pm 10 \mathrm{mg} \cdot \mathrm{kg}^{-1}$, and the increase of up to $466 \pm 44 \mathrm{mg} \cdot \mathrm{kg}^{-1}$ during the period of winter road maintenance. Zítková

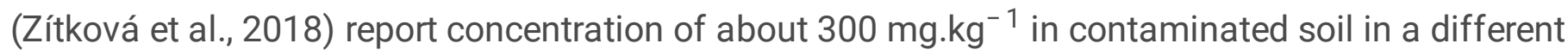
locality of the Czech Republic. The concentrations specified in this study in the humus layer at the distance of $5 \mathrm{~m}$ range from 300 to $1900 \mathrm{mg} \cdot \mathrm{kg}^{-1}$, and from 150 to $800 \mathrm{mg} \cdot \mathrm{kg}^{-1}$ in the subsoil layer. Concentrations determined at the distance of $20 \mathrm{~m}$ are only slightly higher than concentrations at $100 \mathrm{~m}$ and they range in the humus layer from 100 to $200 \mathrm{mg}^{\mathrm{kg}}{ }^{-1}$ and in the subsoil layer from 40 to 150 $\mathrm{mg} \cdot \mathrm{kg}^{-1}$. The results clearly show the influence of de-icing salt on the soil of the selected ecosystem; 
however, we can support the claim that the impact of winter road maintenance is growing insignificant as the distance from the road increases above 20 meters (Munck et al., 2010; Viskari and Kärenlampi, 2000).

Living systems (plants, animals and entire ecosystems) are characterized by great variability in relation to environmental parameters and thus to the effects of winter road maintenance (Černohlávková et al., 2008). Therefore, it is necessary to approach biota individually and to deal primarily with the most sensitive species. The dying of trees near roads is a risk factor for winter road maintenance - these are mainly trees in the alleys planted in the immediate vicinity of the roads, where the simultaneous action of several negative factors is manifested: de-icing salts, covering of a large part of the root system with an impermeable layer of asphalt, the effect of transport emissions and mechanical damage by transport. A second risk group concerns trees in copse forest areas directly adjacent to the road, where the simultaneous action of several negative factors is also manifested: de-icing salts in the form of aerosol and soil salting, transport emissions (especially nitrogen oxides), change of microclimate at the interface between the road body and the forest. Due to these factors, the resistance of trees to drought is also reduced. Chemical contamination analyses are carried out on plant assimilation organs. These are mainly spruce and pine needles, deciduous tree leaves and grass (Semorádová, 2003). The needles have the best bioindication properties since they grow on trees during all seasons and it is possible to collect samples of needles with different age (i.e. needles with different exposure times) (Lachner, 1995).

Determining the health status of trees along the road is an important parameter in the evaluation (Langen and Prutzman, 2006). Based on the results of the sodium concentration obtained, coniferous contamination can be assessed, including tree health state, according to the Contamination Evaluation Scale in Table 2 (Zítková et al., 2018). In a study by Kayama (Kayama et al., 2003), sodium content was also found to be higher in trees with worse state of health.

Table 2

A range of sodium ion concentrations in Norway spruce needles for assessment of the level of contamination.

\begin{tabular}{|lllll|}
\hline Class & level of concentration & tree condition & \multicolumn{2}{l|}{$\mathbf{N a ( m g . \mathrm { kg } ^ { - 1 } )}$} \\
\cline { 4 - 5 } & & & $\mathbf{1}$ year & $\mathbf{2}$ year \\
\hline 1 & normal & healthy & $<600$ & $<700$ \\
\hline 2 & slightly higher & slightly damaged & $700-1900$ & $800-2900$ \\
\hline 3 & high & damaged & $>2000$ & $>3000$ \\
\hline
\end{tabular}

The needle samples analysed in this study fall into all the categories, but if we focus on the needles taken near the road (these correspond to the maximum values in the summary Table 1), the one- and two-years old needles fall into the third category. This is confirmed by the visual assessment of tree health. The determination of sodium (data are available in the supplementary table ST1) as an element indicating the effect of winter road maintenance points to the accumulation of this element in spruce needles (Fig. 2) in all sampling campaigns. With the increasing age of the needles, the sodium content increases, not only at the distance of $5 \mathrm{~m}$ from the road, but also at the further distances. Excessive concentration of this 
element in needles cause them to brown/rust/wilt. The highest concentrations were found in samples taken in spring 2019, which corresponds to the above-discussed larger use of de-icing agents than in the previous year and the following year. The sodium content decreases with distance, it is more than 1000 times lower in needle samples collected at a distance of $100 \mathrm{~m}$.

When comparing the sodium concentrations of samples collected in the spring 2018 campaign and the autumn campaign of the same year, it is noticeable that at the distance of $20 \mathrm{~m}$ and at the background distance of $100 \mathrm{~m}$, the concentration of sodium in the needles of all ages is approximately the same in both sampling campaigns. However, there is a big difference in needles collected at the distance of $5 \mathrm{~m}$, when in autumn samples, the sodium concentration is up to two times higher. It can therefore be assumed that sodium ions are accumulated in the tree during the year, when these cations are likely to be transported from the soil and accepted by the plant, and at the same time the deposition of particles from the air in the needles increases. Forczek (Forczek et al., 2011) applied radioactive $\mathrm{Na}^{36} \mathrm{Cl}$ as a model solution for winter road maintenance and confirmed the effect by recording of visible needle damage. At the same time, there is also a large uptake of de-icing salt dissolved in the soil by the root system; however, the study focused primarily on the $\mathrm{Cl}^{-}$anions. Dependence of salt intake and irrigation has also been detected. Conifers are a commonly used bioindicator due to their ability to capture toxic substances in the surface wax layer on needles and at the same time accumulate substances through the root system of the tree. Their ability to capture persistent organic substances and components of de-icing agents is also verified. Norway spruce is used as a bioindicator of the effects of winter road maintenance on the forest ecosystem (Zítková et al., 2018). The conclusions of our study are also confirmed by Kayama (Kayama et al., 2003), who states that the concentration of sodium in the needles of Norway spruce at the damaged site was significantly higher than that of the healthy site analysed in their study. The concentration of sodium increased with needle aging and was drastically higher at the damaged site (2622 mg.kg-1 for $3+Y, 1909 \mathrm{mg}^{-1} \mathrm{~kg}^{-1}$ for $2 \mathrm{Y}, 1495 \mathrm{mg}^{-\mathrm{kg}^{-1}}$ for $1 \mathrm{Y}$ ) than that at the healthy site (851 mg.kg-1 for $3+\mathrm{Y}, 644 \mathrm{mg} \cdot \mathrm{kg}^{-1}$ for $2 \mathrm{Y}, 621 \mathrm{mg}^{-\mathrm{kg}^{-1}}$ for $1 \mathrm{Y}$ ). Suchara (Suchara et al., 2011) compared the concentration of $\mathrm{Na}$ in mixed $1 \mathrm{Y}$ and $2 \mathrm{Y}$ needles. However, these samples were not under the direct effect of winter road maintenance and they can therefore be considered as background samples. The samples came from the Czech Republic (Suchara et al., 2011), Slovakia (Mankovska, 1998), Norway (Reimann et al., 2001, Reimann et al., 2007). Concentrations in these spruce needles ranged from 6 to $32 \mathrm{mg} . \mathrm{kg}^{-1}$, which is comparable to the contents determined in all campaigns for a distance of $100 \mathrm{~m}$ in our research. In Zítková (Zítková et al, 2018), the concentrations ranged from 42 to $3770 \mathrm{mg} \mathrm{kg}^{-1}$ for one-year old needles of Norway spruce (32 samples) and from 25 to 5107 mg.kg-1 for two-years old needles, depending on the distance from road. The age of spruce needles is an important parameter for the interpretation of the obtained concentrations of elements (e.g., Wyttenbach and Tobler, 2000).

Sodium concentrations in the individual categories of needles (based on their age) in each year evaluated are the basic bioindication output. However, the selected sampling scheme also allows for a different, more detailed interpretation focusing on the specifics of individual winter seasons. Since the sampling campaigns took place three years in a row and samples of individual needle samples were collected 
separately according to their age, it is possible to monitor specific changes occurring within one year. This is based on the fact that the new (OY) needles collected in 2018 become the one-year old needles (1Y) in 2019 and the two-years old (2Y) needles in 2020 (and so forth by analogy). Therefore, direct changes in concentrations in samples occurring during the period from spring to the following spring can be compared. An example of results for the OY and $1 Y$ needles (collected in 2018) is in Table 3. The Table clearly shows the influence of the extreme winter season of 2018/2019 where increased amounts of deicing salts were applied to the road. In all cases, a significant increase in concentrations was observed during this period. However, the situation changes after the following winter season (2019/2020). The increase is recorded only at the distance of $100 \mathrm{~m}$, but near the highway (distances of 5 and $20 \mathrm{~m}$ ), the concentration of $\mathrm{Na}$ actually decreases. The decrease mechanism can be caused by factors both on the side of the transport of the toxic substances in the ecosystem (especially washing of salt trapped on the surface, rainfall etc.) and on the side of uptake of substances by the needles (e.g. damaged vitality of tress due to previous increased doses of salts). The influence of these factors is highest in the area closest to the highway and it decreases with distance (see difference between the distances of 5 and 20 $\mathrm{m})$. Although this evaluation can only be considered as a framework evaluation, it expands the interpretation potential of this bioindication method.

Table 3

Changes in the sodium concentration in needles during individual winter seasons.

\begin{tabular}{|c|c|c|c|}
\hline \multirow[t]{2}{*}{ Distance (m) } & \multirow[t]{2}{*}{ Age of needles in 2018} & \multicolumn{2}{|c|}{ Changes of Na cocnentrations $\left(\mathrm{mg} \cdot \mathrm{kg}^{-1}\right)$ during the year } \\
\hline & & $2018-2019$ & $2019-2020$ \\
\hline \multirow[t]{2}{*}{5} & $0 y$ & 4120 & -1744 \\
\hline & $1 y$ & 4391 & -1281 \\
\hline \multirow[t]{2}{*}{20} & $0 y$ & 231,2 & -40 \\
\hline & 1yy & 179 & -78 \\
\hline \multirow[t]{2}{*}{100} & $0 y$ & 25,1 & 36,5 \\
\hline & $7 y$ & 1,14 & 53,5 \\
\hline
\end{tabular}

When studying other types of biological material, components of the spruce forest ecosystem were selected to provide additional information about the impact of winter road maintenance on the ecosystem. Samples of Schreber's red-stemmed moss (Pleurozium schreberi), forest grass (Avenella flexuosa) and fallen needles were collected. Figure 3 compares the sodium content in all selected matrices in all monitored spring collection campaigns. At the control distances of $20 \mathrm{~m}$ and $100 \mathrm{~m}$, a larger content of $\mathrm{Na}$ is noticeable in moss samples collected in spring 2019, after a period of increased use of de-icing salts. At the distance of $5 \mathrm{~m}$, the content is comparable to the results from other sampling campaigns. Other matrices show comparable results for all sampling campaigns at larger distances (20 $\mathrm{m}$ and $100 \mathrm{~m}$ ); the Na content in fallen needles collected in 2020 at the distance of $20 \mathrm{~m}$ is comparable to the sodium content in moss sample from 2019. At the distance of $5 \mathrm{~m}$, the distribution of contamination 
in individual campaigns is uneven; the high content detected in the samples of grass and moss of the 2020 collection campaign is interesting, it can be attributed to the accumulation from the previous winter, when much higher amounts of de-icing materials were used. Overall, the sodium content in fallen needles and moss is higher than in the grass samples for all sampling campaigns. Moss receives pollutants mostly from the air, since it has a very small root system; it is therefore assumed that the contamination was received from de-icing material scattered on the site. Figure 3 shows high sorption capacity of moss when comparing sodium concentrations in the individual selected components of the ecosystem, the moss samples have the highest sodium content at all distances from the road. Moss is used worldwide for its cumulative capabilities to evaluate the nature and intensity of pollution in the environment by heavy metals and gaseous substances (Alam, 2018, Suchara et. al., 2011) analysed moss (Pleurozium schreberi), grass (Avenella flexuosa; syn. Deschampsia flexuosa) and their results show the highest sodium content in grass samples, i.e. $14 \mathrm{mg} \cdot \mathrm{kg}^{-1}$, which is a concentration comparable to the concentration we detected in the background area at the distance of $100 \mathrm{~m}$. However, their study (Suchara et al., 2011) do not focus on areas with a possible contamination caused by winter road maintenance, but rather on wider blanket monitoring. In their work, they compare the results with the results obtained from monitoring in northern Europe, where the $\mathrm{Na}$ content in grass samples was around $40 \mathrm{mg} \cdot \mathrm{kg}^{-1}$ (values expressed as median). This value also corresponds to the background area.

Cortis (Cortis et al., 2016) monitored the accumulation of pollutants in a contaminated area using active biomonitoring with moss sacs and compared it with a control area in Italy. They focused on analysis of 15 elements, including sodium. The sodium content ranged from 1000 to $1500 \mathrm{mg} \cdot \mathrm{kg}^{-1}$; it was only slightly lower in the background area. The values are comparable to those determined for the samples taken in the vicinity of the road. Similarly, Saitanis (Saitanis et al., 2013), used moss in the heavily polluted Thriasion Plain area of Attica, Greece, to study the distribution of 32 elements in the atmosphere, including $\mathrm{Na}$. At first, there was an increasing trend in the sodium concentration during winter and early spring, but it drastically decreased during the later warm period; this trend is also confirmed by our study, where the concentration of $\mathrm{Na}$ in moss and grass decreases during the year, as is visible in Fig. 3.

The publications cited agree on the useful function of trees and other vegetation as barriers against salt sprayed from the road. Preventing the spraying of de-icing material into the surrounding area is very important to avoid further effects on vegetation, because these sprays have been found to have a greater effect on salt accumulation compared to the uptake of salt from the root system (Munck et al., 2010; Pedersen et al., 2000; Viskari and Kärenlampi, 2000). Our study also confirms this conclusion. Křenová (Křenová et al., 2018) monitored the effects of de-icing salts on ecosystems of National Park and stated that the chemicals from the roads are mostly transported via runoff of rainwater from the road through the soil. Subsequently, these effluents, absorbed by plants, can affect ecosystems over considerable distance (Angold, 1997). The Olivier study (Olivier et al., 2020) examined the relationship between $\mathrm{Na}$ and $\mathrm{Cl}$ ions absorption, $\mathrm{Na}$ and $\mathrm{Cl}$ concentrations in plant tissue and plant damage in seedlings of three conifers commonly used for oil sands reclamation, including black spruce (Picea mariana), white spruce (Picea glauca) and jack pine (Pinus banksiana). In this study a significant correlation was found between 
the concentrations of $\mathrm{Na}$ and $\mathrm{Cl}$ in needles and the extent of necrosis. A study of the accumulation of deicing salt ions used for winter road maintenance in Scots pine assimilation organs confirmed higher concentrations of $\mathrm{Na}$ and $\mathrm{Cl}$ ions in locations immediately adjacent to roads (Zítková et. al., 2021). Hofstra, (Hofstra and Smith, 1984) analysed leaf injury of pine and white cedar in relation to foliar levels of sodium. Studies suggest using the $\mathrm{Na}$ and $\mathrm{Cl}$ concentration in plant tissue as an effective monitoring tool for estimating the damage caused by salt to conifers grown in areas affected by $\mathrm{NaCl}$, because salt accumulation in spruce and pine needles has been found to directly correlate with the amount of chemical de-icing materials used on surrounding roads (Viskari and Kärenlampi, 2000, Fostad and Pedersen, 2000; Kayama et al., 2003; Zítková et al., 2018; Zítková et al., 2021).

\subsection{Statistical evaluation}

Statistical calculations were made using R statistical software (https://www.r-project.org/) using libraries rpsychi for calculation of two-way ANOVA (Cohen, 2002, Huck and Malgady, 1978) and ggplot2 for visualization of the results. Differences of confidence intervals in the plots were evaluated according to Cumming (Cumming, 2012). An obvious dependence of sodium concentration in the samples on distance from the road are shown in Fig. 3, Fig. 4 (left), Table 1 and Supplementary table ST1. There are also distinct differences in sodium concentrations between various types of samples (fallen needles, moos, grass, humus or soil). The importance of the sample type and the distance from the road was also evaluated using two-way ANOVA. Both factors, distance from the road and the sample type, were found to be statistically significant on the confidence level $a=0.05$. However, no statistically significant interaction between these factors (relationship between type of sample and the distance) was identified. Trends in the sodium content, with regard to types of samples, differ for the various seasons (spring 2018 - spring 2020, Fig. 4 (right) and Supplementary table ST1) and no trend in the data can be generalized for all seasons. Visualization of the data (Fig. 2 and Fig. 5 (left), Tables 1 and 3 and Supplementary table ST1) show an obvious dependence of sodium concentration in needles on the distance from the road. Sodium concentration in the needles (Figs. 2 and 5 (right)) was also found to increase with their age (OY, $1 Y, 2 Y$ or $3+Y)$. The importance of age of the needles and the distance from the road was also evaluated using two-way ANOVA. Both these factors were found to be significant, and their interaction was not (on the confidence level $a=0.05$ ).

\section{Conlusion}

The aim of this study was to use the analytical data for a risk assessment of the environmental contamination near the highway, caused by the use of sodium chloride in winter maintenance. Soil is the final recipient of a wide range of contaminants, which can also enter the food chain from the soil. The analysis of the potential influence of winter road maintenance on the environment focused on all components of the environment of the selected conifer forest ecosystem - Norway spruce (Picea abies). The study of the impact of winter road maintenance found high sodium concentrations in samples collected from areas near the road. A deterioration in the health of spruces, which grew in close proximity to the road, i.e. at a sampling distance of $5 \mathrm{~m}$, was also observed. The needles of these spruce trees 
showed increased sodium concentrations, regardless of the age of the needles. Spruce is thus a suitable bioindicator of the effects of chemical winter road maintenance due to its increased sensitivity to salting and its abundant occurrence in the area of interest. The results suggest that salting has an effect on local ecosystems, especially near the road (approx. up to $20 \mathrm{~m}$ ) because of sodium accumulates in all selected components of the analysed ecosystem (moos, humus, soil). Different species have a different tolerance to salt, which can lead to changes in species composition and affect interspecies competition. Obtained results evaluate significant impact of contamination in close proximity to the road, which decrease significantly with distance from the road to cca $20 \mathrm{~m}$. This value can be regarded as a limit of significant impact. Additionally, an impact of sodium ions spreading via aerosol was proved. This impact is noticeable in distance $100 \mathrm{~m}$. It was proven by changes of sodium concentrations in various ecosystem components (especially in grass, moos and humus), reflecting variability of winter maintenance in particular years. Although significant impact cannot be expected for the ecosystem vitality, attention should be paid to this problem. Moreover, impact of sodium ions in distances up to $100 \mathrm{~m}$ and also to possible synergy with other contaminants from the traffic should be examined. A more detailed investigation is needed to determine the extent to which an increase of sodium concentration may affect structure and linkages in the ecosystem. It would be appropriate to focus not only on the impact of winter maintenance, but also on other synergistic effects of transport.

\section{Declarations}

\section{Acknowledgements}

This article was produced with the financial support of the Ministry of Transport within the programme of long-term conceptual development of research institutions.

\section{Ethics approval and consent to participate}

Not applicable.

\section{Consent for publication}

Not applicable.

\section{Availability of data and materials}

The datasets analysed during the current study are available from the corresponding author on reasonable request. Data are included in this published article as supplementary information file.

\section{Authors' contributions}

$\mathrm{JH}$ analysed all samples and prepared data for interpretation, interpreted data, LP interpreted data and prepared a statistical evaluation, PA described the evaluated data and prepared theoretical hypotheses, 
MB and VJ were focused on mechanical treatment of samples and digestion of samples, KF was focused on collection of samples, $\mathrm{RL}$ corrected data interpretation and text.

\section{Declaration of interests}

The authors declare that they have no known competing financial interests or personal relationships that could have appeared to influence the work reported in this paper.

\section{Funding}

This article was produced with the financial support of the Ministry of Transport within the programme of long-term conceptual development of research institutions. Ministry of Transport expressed interest in the implementation of the study and results, obtained by this study.

\section{References}

1. Alam A (2018) Bryomonitoring of environmental pollution. In: Vats S. (eds) Biotic and abiotic stress tolerance in plants. Springer, Singapore, ISBN: 978-981-10-9029-5, pp. 349-366. https://doi.org/10.1007/978-981-10-9029-5_13

2. Angold PG (1997) The impact of a road upon adjacent heathland vegetation: Effects on plant species composition. J Appl Ecol 34(2):409-417. https://doi.org/10.2307/2404886

3. Bogemans J, Neirinckx L, Stassart JM (1989) Effect of deicing chloride salts on ion accumulation in spruce (Picea abies (L.) sp. Plant Soil 113:3-11. https://doi.org/10.1007/BF02181915

4. Cohen BH (2002) Calculating a factorial ANOVA from means and standard deviations. Understanding Statistics 1(3):191-203. https://doi.org/10.1207/S15328031US0103_04

5. Cumming G (2012) Understanding the new statistics. Effect Sizes, Confidence Intervals, and Metaanalysis. Routledge, New York, 2012. ISBN: 978-0-415-87968-2

6. Cortis P, Vannini C, Cogoni A, De Matia F, Bracale M, Mezzasalma V, Labra M (2016) Chemical, molecular, and proteomic analyses of moss bag biomonitoring in a petrochemical area of Sardinia (Italy). Environ Sci Pollut Res 23:2288-2300. https://doi.org/10.1007/s11356-015-5393-7

7. Czerniawska-Kusza I, Kusza G, Duzynski M (2004) Effect of deicing salts on urban soils and health status of roadside trees in the Opole region. Environ Toxicol 19(4):296-301. https://doi.org/10.1002/tox.20037

8. Černohlávková J, Hofman J, Bartoš T, Sáňka M, Anděl P (2008) Effects of road deicing salts on soil microorganisms. Plant Soil Environment 54(11):479-485. https://doi.org/10.17221/431-PSE

9. Dmuchowski W, Brogowski Z, Bacewska AH (2011) Evaluation of vigour and health of "street" trees using foliar ionic status. Polish Journal of Environmental Studies 20(2):489-496 online: www.pjoes.com/pdf-88582-22441

10. Fay L, Shi X (2012) Environmental impacts of chemicals for snow and ice control: State of the knowledge. Water Air Soil Pollution 223(5):2751-2770. https://doi.org/10.1007/s11270-011-1064-6 
11. Fay L, Shi X, Huang J (2013) Strategies to Mitigate the Impacts of Chloride Roadway Deicers on the Natural Environment. A synthesis of highway practice. Synthesis 449. National Cooperative Highway Research Program (NCHRP). Washington, D.C: Transportation Research Board, ISBN 978-0-30927093-9. https://doi.org/10.13140/2.1.1360.2249

12. Fischel M (2001) Evaluation of selected deicers based on a review of the literature. Colorado dept. of transportation, research branch. Report No. CDOT-DTD-R-2001-15, Denver, Colorado. online: https://www.codot.gov/programs/research/pdfs/2001/deicers.pdf

13. Forczek ST, Benada O, Kofroňová O, Sigler K, Matucha M (2011) Influence of road salting on the adjacent Norway spruce (Picea abies) forest. Plant Soil Environmental 57(7):344-350. https://doi.org/10.17221/356/2010-PSE

14. Fostad O, Pedersen PA (2000) Container-grown tree seedling responses to sodium chloride applications in different substrates. Environ Pollut 109(2):203-210. https://doi.org/10.1016/S02697491(99)00266-3

15. Gałuszka A, Migaszewski ZM, Podlaskil R, Dołęgowska S, Michalik A (2011) The influence of chloride deicers on mineral nutrition and the health status of roadside trees in the city of Kielce, Poland. Environ Monit Assess 176(1-4):451-464. https://doi.org/10.1007/s10661-010-1596-z

16. Hääl ML, Sürje P, Rõuk H (2008) Traffic as a source of pollution. Est J Eng 57(1):65-82. https://doi.org/10.3176/eng.2008.1.05

17. Hofman J, Trávníčková E, Anděl P, 2012. Road salts effects on soil chemical and microbial properties at grassland and forest site in protected natural areas. Plant, Soil and Environment, 58(6), 282-288. https://doi.org/10.17221/5994-PSE

18. Hofstra G, Smith DW (1984) Effect of road deicing salt on the levels of ions in roadside soil in southen Ontario. J Environ Manage 19:261-271

19. Howard KWF, Beck PJ (1993) Hydrogeochemical implications of groundwater contamination by road de-icing chemicals. J Contam Hydrol 12(3):245-268. https://doi.org/10.1016/0169-7722(93)90010$P$

20. Huck SW, Malgady RG (1978) Two-way analysis of variance using means and standard deviations. Educ Psychol Measur 38(2):235-237. https://doi.org/10.1177/001316447803800204

21. Izuta T (1998) Ecophysiosical responses of Japanese forest tree species to ozone, simulated acid rain and soil acidification. J Plant Res 111:471-480. https://doi.org/10.1007/BF02507781

22. Kayama M, Quoreshi AM, Kitaoka S, Kitahashi Y, Sakamoto Y, Maruyama Y, Kitao M, Koike T (2003) Effects of deicing salt on the vitality and health of two spruce species, Picea abies Karst., and Picea glehnii Masters planted along roadsides in northern Japan. Environ Pollut 124:127-137. https://doi.org/10.1016/S0269-7491(02)00415-3

23. Křenová Z, Zýval V, Zýval V Jr, Chocholoušková Z (2018) Increasing concentration of deicing salt in soils in the Bavarian Forest National Park. European Journal of Environmental Sciences 8(2):109116. https://doi.org/10.14712/23361964.2018.15 
24. Lachner W Physiological Plant Ecology. Fifth ed., Springer-Verlag, Berlin (1995) ISBN 978-3-54043516-7

25. Langen TA, Prutzman H (2006) The effects of chemical road deicers on surrounding boreal forests and lakes. In: Langen, T.A., Twiss, M., Young, T., Janoyan, K., Stager, J.C., Osso, J.Jr., Prutzman, H., Green, B. (eds), Environmental impacts of winter road management at the Cascade Lakes and Chapel Pond. Clarkson Center for the Environment Report \#1, New York State Department of Transportation, New York, pp. 15-48. online:

https://www.dot.ny.gov/divisions/engineering/environmental-

analysis/repository/cascade_lakes_final_report.pdf

26. Lazof D, Läuchli A (1991) The nutritional status of the apical meristem of Lactuca sativa as affected by $\mathrm{NaCl}$ salinization: An electron-probe microanalytic study. Planta 184:334-342. https://doi.org/10.1007/BF00195334

27. Löfgren S (2001) The chemical effects of deicing salt on soil and stream water of five catchments in Southeast Sweden. Water Air Soil Pollution 130(1/4):863-868. https://doi.org/10.1023/A:1013895215558

28. Mankovska B (1998) The chemical composition of spruce and beech foliage as an environmental indicator. in Slovakia Chemosphere 36:949-953. https://doi.org/10.1016/S0045-6535(97)10153-9

29. Merrikhpour $\mathrm{H}$, Jalali $M(2013)$ The effects of road salt application on the accumulation and speciation of cations and anions in an urban environment. Water Environment Journal 27(4):524534. https://doi.org/10.1111/j.1747-6593.2012.00371.x

30. Munck IA, Bennet ChM, Camilli KS, Nowak RS (2010) Long-term impact of de-icing salts on tree health in the Lake Tahoe Basin: Environmental influences and interactions with insects and diseases. For Ecol Manage 260(7):1218-1229. https://doi.org/10.1016/j.foreco.2010.07.015

31. Olivier S, Zhang WQ, Zwiazek JJ (2020) Tissue sodium and chloride concentrations in relation to needle injury in boreal conifer seedlings subjected to salt stress. Trees 34:521-529. https://doi.org/10.1007/s00468-019-01933-3

32. Pedersen LB, Randrup TB, Ingerslev M (2000) Effects of road distance and protective measures on deicing $\mathrm{NaCl}$ deposition and soil solution chemistry in planted median strips. J Arboric 26(5):238245

33. Ramakrishna DM, Viraraghavan T (2005) Environmental impact of chemical deicers - A Review. Water Air Soil Pollution 166(1-4):49-63. https://doi.org/10.1007/s11270-005-8265-9

34. Reimann C, Arnoldussen A, Boyd R, Finne TE, Koller F, Nordgulen $\varnothing$, Englmaier $P$ (2007) Element contents in leaves of four plant species (birch, mountain ash, fern and spruce) along anthropogenic and geogenic concentration gradients. Science of theTotal Environment 377:416-433. https://doi.org/10.1016/j.scitotenv.2007.02.011

35. Reimann C, Koller F, Frengstad B, Kashulina G, Niskavaara H, Englmaier P (2001) Comparison of the element composition in several plant species and their substrate from a 1,500,000 km²-area in Northern Europe. Sci Total Environ 278:87-112. https://doi.org/10.1016/S0048-9697(00)00890-1 
36. Saitanis CJ, Frontasyeva MV, Steinnes E, Palmer MW, Ostrovnaya TM, Gundorina SF (2013) Spatiotemporal distribution of airbone elements monitored with the moss bags technique in the Greater Thriasion Palin, Atica, Greece. Environ Monit Assess 185(1):955-968. https://doi.org/10.1007/s10661-012-2606-0

37. Semorádová E (2003) Damage to forest stands with sprinkled salt. Forestry work, 82 (01/03), online: http://www.lesprace.cz/casopis-lesnicka-prace-archiv/rocnik-82-2003/ lesnicka-prace-c-0103/poskozovani-lesnich-porostu-posypovou-soli cit. 26. 2. 2021Schulze, E. D., 1989. Air pollution and forest decline in a spruce (Picea abies) forest. Science 244, 776-783. https://doi.org/10.1126/science.244.4906.776

38. Suchara I, Sucharova J, Hola M, Reimann C, Boyd R, Filzmoser P, Emglmaier P (2011) The performance of moss, grass, and 1- and 2-year old spruce needles as bioindicators of contamination: a comparative study at the scale of the Czech Republic. Science Of the Total Environment 409(11):2281-2297. https://doi.org/10.1016/j.scitotenv.2011.02.003

39. Syvertsen JP, Lloyd J, Kriedemann PE (1988) Salinity and drought stress effects on foliar ion concentrations, water relations, and photosynthetic characteristics of orchard citrus. Aust J Agric Res 39:619-627. https://doi.org/10.1071/AR9880619

40. Vignisdotir HR, Ebrahimi B, Booo GK, O'born R, Bratebø H, Wallbaum H, Bohne RA (2019) A review of environmental impacts of winter road maintenance. Cold Regions Science Technology 158:143-153. https://doi.org/10.1016/j.coldregions.2018.10.013

41. Viskari EL, Kärenlampi L (2000) Roadside Scots pine as an indicator of deicing salt use - A comparative study from two consecutive winters. Water Air Soil Pollution 122(3/4):405-419. https://doi.org/10.1023/A:1005235422943

42. Wyttenbach A, Tobler $L$ (2000) The concentrations of Fe, $\mathrm{Zn}$ and $\mathrm{Co}$ in successive needle age classes of Norway spruce (Picea abies (L.) Karst.). Trees 14:198-205. https://doi.org/10.1007/PL00009763

43. Zítková J, Hegrová J, Anděl P (2018) Bioindication of road salting impact on Norway spruce (Picea abies). Transportation Research Part D: Transport Environment 59:58-67. https://doi.org/10.1016/j.trd.2017.12.010

44. Zítková J, Hegrová J, Keken Z, Ličbinský R (2021) Impact of road salting on Scots pine (Pinus sylvestris) and Norway spruce (Picea abies). Ecol Eng 159:106129. https://doi.org/10.1016/j.ecoleng.2020.106129

\section{Figures}




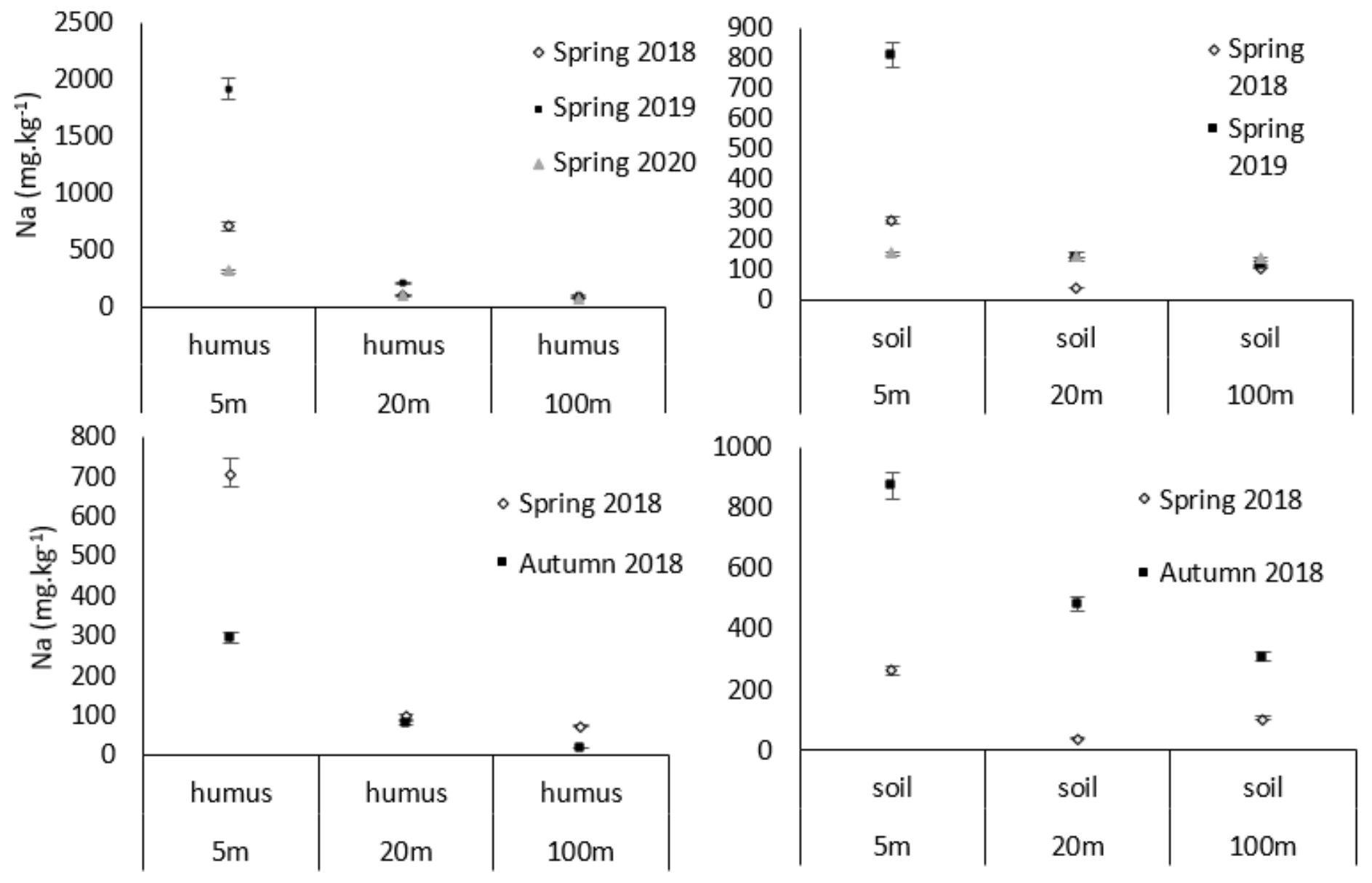

Figure 1

Difference in sodium concentrations in the humus and soil layers at the selected area of the D1 motorway in all spring periods and two monitoring periods of 2018 at different distances from the road

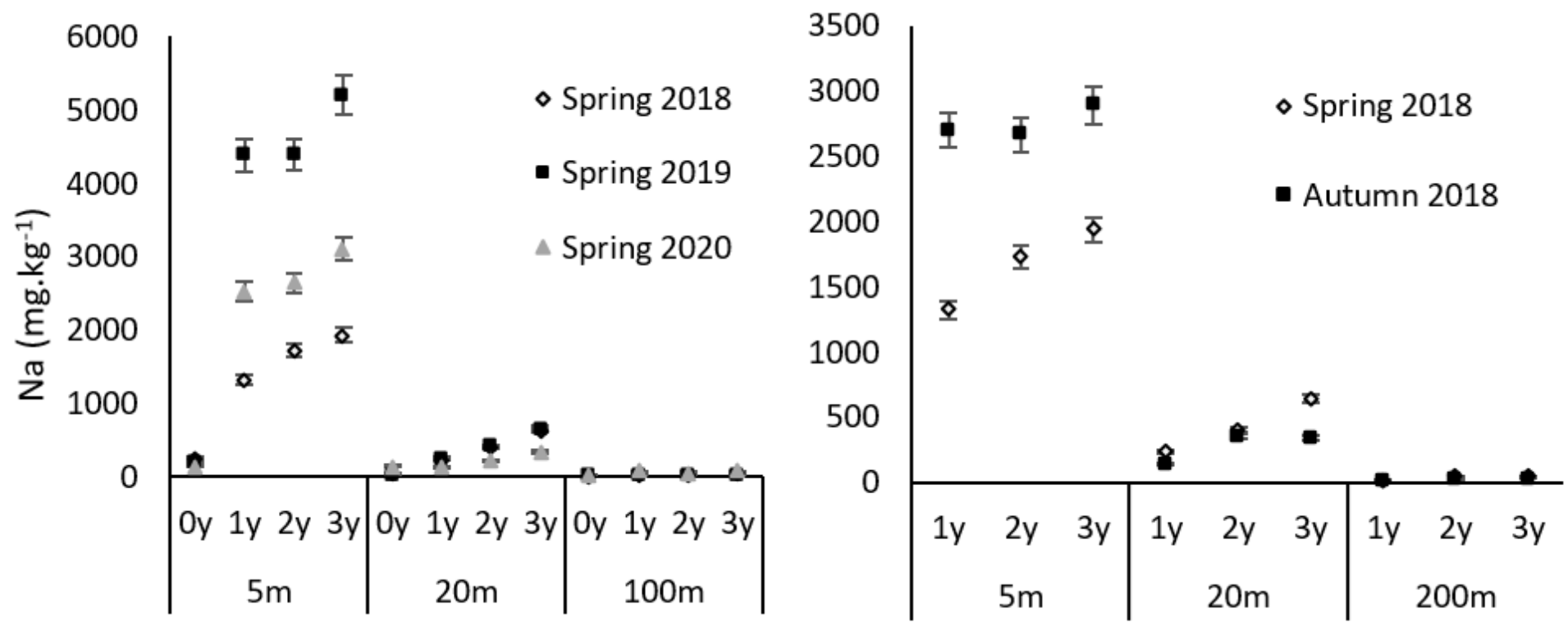

Figure 2 
Comparison of sodium concentrations in needles of different ages over three sampling distances in all spring sampling campaigns and in the 2018 spring and autumn campaigns

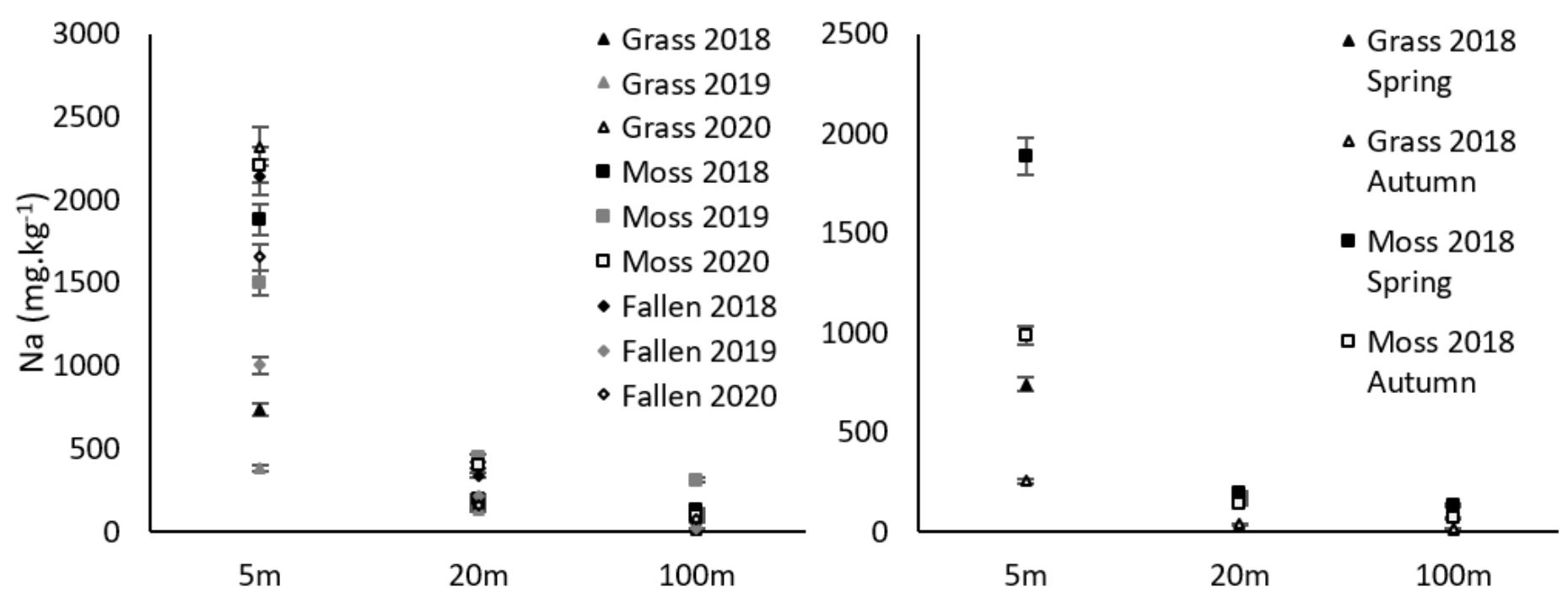

\section{Figure 3}

Comparison of sodium concentration in samples of grass, moss and fallen needles in all spring sampling campaigns, comparison of spring and autumn 2018 campaigns
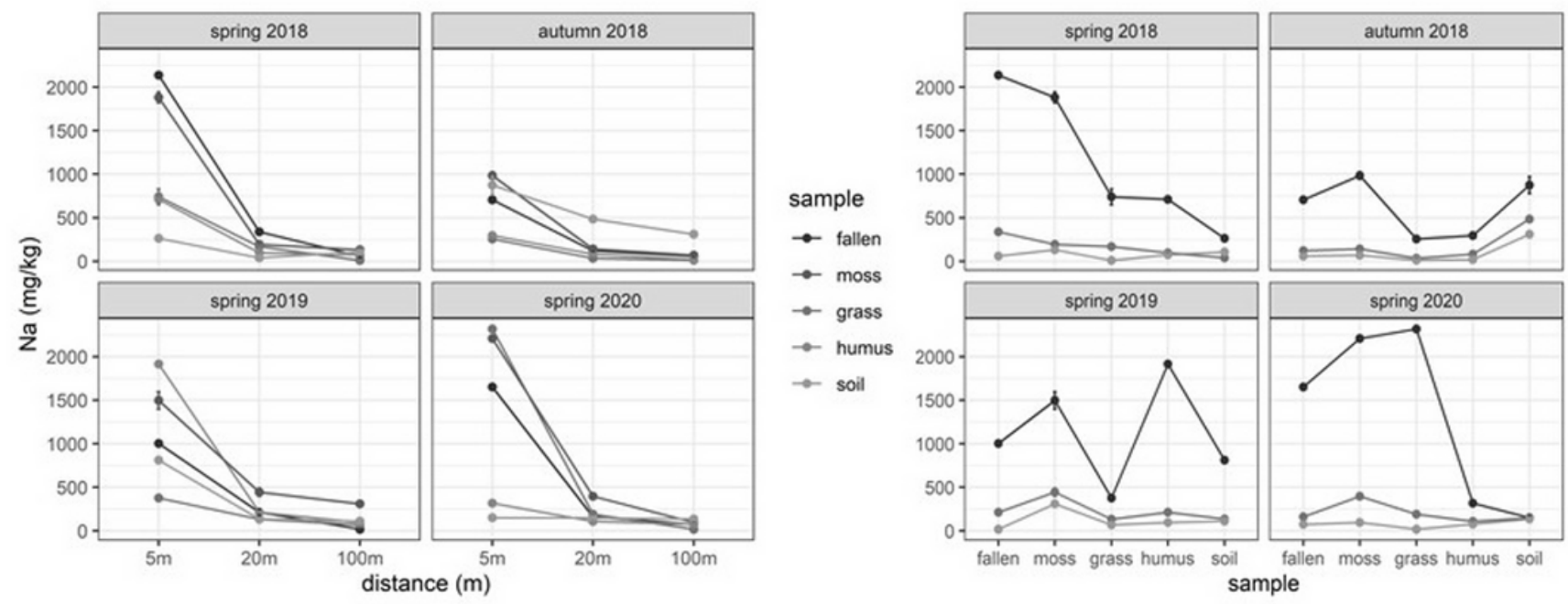

distance $(m)$

$\rightarrow 5 m$

$\rightarrow 20 \mathrm{~m}$

$\rightarrow 100 \mathrm{~m}$

\section{Figure 4}

Dependence of sodium concentration in the different type of samples on distance from the road (left) and differences in sodium concentrations between various types of samples (right) 

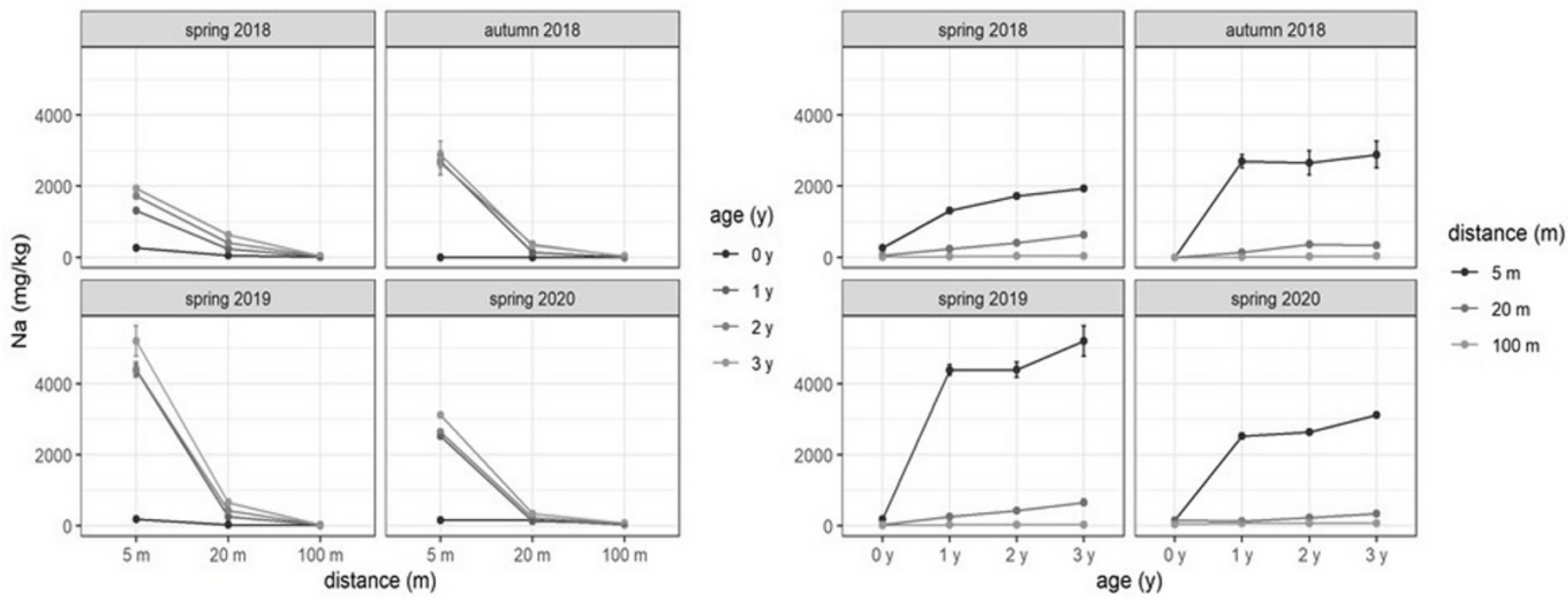

Figure 5

Dependence of sodium concentration in different age needles on the distance from the road (left) and differences in sodium concentrations between needles of different age (right)

\section{Supplementary Files}

This is a list of supplementary files associated with this preprint. Click to download.

- SupplementaryTableST1.docx 